Egyptian Poultry Science Journal

http://www.epsaegypt.com

ISSN: 1110-5623 (Print) - 2090-0570 (On line)

\title{
EFFECT OF USING DIFFERENT LEVELS AND SOURCES OF ZINC IN LAYER'S DIETS ON EGG ZINC ENRICHMENT
}

\author{
A.S.A. Bahakaim ${ }^{1}$.Hmat.A.Abdel Magied ${ }^{1}$.Sahar.M.H.Osman ${ }^{1}$, Amal S.Omar ${ }^{2}$ \\ N.Y.AbdelMalak ${ }^{1}$ and Nehad, A.Ramadan ${ }^{{ }^{*}}$ \\ ${ }^{1}$ Poul. Nutrition Dep., ${ }^{2}$ Anim. Prod. Systems Rese. Dep., Anim. Prod. Rese. Institute, Agric. \\ Rese. Center, Ministry of Agric., Egypt
}

Received: 30/11/2013

Accepted: 30/01/2014

\begin{abstract}
One hundred and twenty Golden Montazah laying hens (Egyptian local developed strain) aged 24 weeks were divided in two groups each group contains four treatments with two different supplemental sources of zinc, inorganic zinc as zinc sulphate $\left(\mathrm{ZnSo} 47 \mathrm{H}_{2} \mathrm{O}\right)$ and organic zinc as zinc methionine to get concentration levels $0.0,50,100$ and $150 \mathrm{mg}$ supplemental zinc/kg diet to investigate the effect of different dietary levels and sources of zinc and their interaction on the zinc concentration of egg, the productive performance, some egg quality and some blood parameters of laying hens were also estimated. The experimental period lasted for 12 weeks in three subsequent interval periods (four weeks each). Results indicated that increasing zinc levels from 0.0 up to $150 \mathrm{mg} / \mathrm{kg}$ either as inorganic or organic significantly increased egg zinc concentration without any adverse effect on egg production. The highest concentration of egg zinc was observed for layers fed diet supplemented with $150 \mathrm{mg}$ zinc/ $\mathrm{kg}$ diet as an organic $\mathrm{Zn}$ ( $\mathrm{Zn}$ methionine). Supplementing laying hens' diet with zinc as zinc methionine significantly increased egg production. In that, $100 \mathrm{mg}$ supplemental zinc as $\mathrm{Zn}$ methionine gave the best feed conversion and egg mass. Also, organic zinc supplementation significantly increased plasma zinc, total protein, albumen, and globulin and improved A/G ratio. Albumen index and Haugh unit significantly affected by increasing zinc levels.

In conclusion supplemented laying hens diet with $150 \mathrm{mg}$ zinc as zinc methionine / $\mathrm{kg}$ diet gave zinc enriched egg which could supply $19.45 \%$ of daily requirements of zinc for children from 1-8 years and additionally gave advancement in productive performance for laying hens.
\end{abstract}

Key Words: Zinc, layer's diets on egg zinc enrichment.

*Corresponding author: nehad.a_r31@yahoo.com 


\section{INTRODUCTION}

Zinc has significant roles in the organism probably because it is a cofactor of more than 200 enzymes. One of the most significant functions of zinc is related to its antioxidant role and its participation in the antioxidant defense system (Powell, 2000). Zinc deficiency provokes oxidative damage through the effect of free radical action and alters the status antioxidant enzymes and substances (Salgueiro et al.2000).

The mechanism by which zinc exerts its antioxidant action is not well defined. However it has been suggested that zinc increases the synthesis of metallothioneine which acts as a free radical scavenger (Bales et al. 1994 and Close, 1999). Zinc is an essential component of both DNA and RNA polymerase enzymes and is vital to the activity of variety hormones including glucagon insulin, growth and sex hormones. Zinc is an integral part of more than 300 enzyme systems that are involved in metabolism of energy, carbohydrates, nucleic acids and protein. Moreover, zinc plays a key role in the immune system, transport and use of vitamin A (Ibs and Rink, 2003).

Deficiency of trace elements in human nutrition represent a big problem. It has been estimated that third of the world population suffers from $\mathrm{Zn}$ deficiency, which accounts about $1.4 \%$ of total mortality (WHO, 2002). FAO (2012) reported that $\mathrm{Zn}$ deficiency affect on about milliard person in the third world. Also, it causes many problems especially with kids like growth retard, delay sexual maturity and decrease immunity. These lead to the death of 800000 chiled every year in the world. Egyptian doesn't consume sufficient basic nutrition elements, six elements absent in Egyptian food such as $\mathrm{Zn}$, vitamin $\mathrm{A}, \mathrm{Fe}, \mathrm{Ca}$, I and $\mathrm{Se}$. children between 1-8 years need 5-6 mg $\mathrm{Zn}$ daily while the adults above 19 years needs about 4-9 mg daily. Ibs and Rrink, (2003) indicated that Zinc is commonly supplemented in the diets for laying hens and other livestock because most of ingredients are marginally $\mathrm{Zn}$ deficient. Organic complexes of zinc have been proposed to be more available source of zinc for layer hens (Aliarabi et al. 2007) and may be metabolized differently than inorganic forms (Spears 1989). Znmethionine or Zn-propionate had more bioavailability than inorganic zinc sources such as $\mathrm{ZnO}$ or $\mathrm{ZnSo}_{4} \mathrm{H}_{2} \mathrm{O}$ (Rahman et al., 2002). Khajaren et al. (2006) observed improvements in egg production for layers fed organic zinc. The improvements achieved by zinc supplementation may be due to that zinc involved in many biochemical processes supporting life (Chan et al. 1998). Mahmood et al. (2011) suggested that diets of brown parent stock layers should include $180 \mathrm{mg}$ zinc $/ \mathrm{kg}$ for optimal performance and hatchability traits. However, Tabatabaie et al. (2007) reported that, feed conversion, egg mass did not affect significantly when layer hens fed diet containing zinc sulphate or organic zinc as Albino-Zn up to $50 \mathrm{ppm}$. Atukorala and Waidyanatha (1987) indicated that, eggs contained large amounts of zinc compared to that of milk, and they added that while zinc is present in significant amounts in pulses and cereals it may be less bioavailable because of high phytate.

Therefore, this study aimed to investigate the influence of varying levels and sources of zinc in laying hen diet on egg zinc enrichment to give a hand in solving the problem of zinc deficiency for human in Egypt.

\section{MATERIALS AND METHODS}

The present study was carried out at Inshas Poultry Research Station, (ElSharkia Governorate). Animal Production Research Institute, Agriculture Research Center.

A total number of 120 Golden Montazah laying hens (Egyptian local developed strain) 24-Wk-old were 
randomly taken from the farm flock, to be similar in weight and productivity. They were distributed into 8 treatments, (15 layers each in 3 replicates). All birds were kept individually in layer's cages under the same managerial condition. Feed and water were provided ad libitum. Hens received the basal layers diet which consisted primarily of corn and soybean meal. The basal layer diets covered all the essential nutrients according to the ministerial decree No. 1498. The analytic values of the basal diet were tabulated in Table 1.

Table (1): Composition and calculated analysis of the experimental diets.

\begin{tabular}{|l|l|}
\hline \multicolumn{1}{|c|}{ Ingredient } & \multicolumn{1}{c|}{$\%$} \\
\hline yellow Corn & 64.74 \\
Soybean meal 44\% & 25.03 \\
DL- Methionine(99\%) & 0.02 \\
Calcium carbonate & 8.12 \\
Di. Calcium. phosphate. & 1.42 \\
NaCl & 0.37 \\
Vitamin and Minerals premix* & 0.30 \\
Total & 100 \\
\hline Calculated analysis & \\
\hline ME( kcal/kg ) & 2719 \\
CP \% & 16.00 \\
CF \% & 3.30 \\
Ca \% & 3.43 \\
Av. P \% & 0.38 \\
Lysine & 0.89 \\
Methionine \% & 0.39 \\
Methionin + Cystine \% & 0.62 \\
\hline Supplied per kg of dit: Vit. A, 12000 IU; Vit. D3, $220010 ;$ Vit. E, 10 mg; Vit
\end{tabular}

* Supplied per kg of diet: Vit. A, 12000 IU; Vit. D3, 2200 IU; Vit. E, 10 mg; Vit K3, 2mg; Vit. B1, 1mg; Vit. B2 5mg; B6 1.5mg; B12 $10 \mathrm{mcg}$; Nicotinic acid 30mg; Folic acid 1mg, Pantothenic acid 10mg; Biotein $50 \mathrm{mcg}$; Choline 250mg; Copper 10mg; Iron 30mg; Manganse 60mg; Zinc 50mg; Iodine $0.3 \mathrm{mg}$; Selenium $0.1 \mathrm{mg}$; Cobalt $0.1 \mathrm{mg}$.

The experimental period lasted for 12 weeks in three subsequent interval periods (four weeks each). The layers divided in two groups every group contains four treatments with different supplemental source of zinc, inorganic zinc $\left(\mathrm{ZnSo}_{4} 7 \mathrm{H}_{2} \mathrm{O}\right)$ and organic zinc (zinc - methionine) to get zinc concentration levels $0.0,50,100$ and
$150 \mathrm{mg}$ zinc/Kg diets over the requirements (50 $\mathrm{mg} / \mathrm{kg}$ diet) in factorial arrangement $(2 \times 4)$ as shown in Table 2 . Every group has one treatment of layers received the basal diet containing the requirement of zinc (50 $\mathrm{mg}$ zinc/ $\mathrm{kg}$ diet either as inorganic or organic) which assigned as the control treatment. 
Table (2): Experimental design.

\begin{tabular}{|l|c|c|c|c|}
\hline \multirow{2}{*}{ Sources of zinc supplementation } & \multicolumn{4}{|c|}{$\begin{array}{c}\text { Levels of zinc supplementation } \\
\text { mg zinc/kg diet }\end{array}$} \\
\hline Inorganic $\left(\mathrm{ZnSO}_{4} .7 \mathrm{H}_{2} \mathrm{O}\right)$ & Control & $50 \mathrm{gm}$ & $100 \mathrm{mg}$ & $150 \mathrm{mg}$ \\
Organic (zinc methionine) & Control & $50 \mathrm{mg}$ & $100 \mathrm{mg}$ & $150 \mathrm{mg}$ \\
\hline
\end{tabular}

The productive traits were calculated as egg/hen/period for each replicate during the three interval periods (from 24 to $36 \mathrm{Wks}$ of age). Egg mass was calculated by multiplying egg number by average egg weight. Feed conversion was calculated as $\mathrm{Kg}$ feed consumption divided by $\mathrm{Kg}$ egg mass ( $\mathrm{Kg}$ feed $\backslash \mathrm{Kg}$ egg). Egg quality was measured at the end of each interval period, in which 18 eggs were randomly taken from each treatment (6 eggs from each replicate). Eggs were individually broken out, shape index, albumen and yolk index values were measured according to Sauter et al., (1951) in addition to shell, yolk, and albumen percentages were calculated according to Paganelli et al., (1974) Also Haugh units were done according to Williams (1997).

The concentrations of $\mathrm{Zn}$ $(\mathrm{mg} / 100 \mathrm{gm}$ egg) were determined in 6 chosen randomly eggs for each treatment in the principal center lab (Cairo UniversityFaculty of Agriculture); samples were digested by the Advanced Microwave Digestion System and measured by ICP spectrometer (ICAP 6000 series; Thermo Scientific).

At the end of the study, blood samples were collected from 3 hens randomly taken from each treatment. Blood was centrifuged at $3000 \mathrm{rpm}$ for $10 \mathrm{~min}$ and plasma separated, then stored at $-20^{\circ} \mathrm{c}$ for analysis. Zinc $(\mathrm{mg} / \mathrm{dl})$, iron $(\mathrm{mg} / \mathrm{dl})$, calcium $(\mathrm{mg} / \mathrm{dl})$, phosphor $(\mathrm{mg} / \mathrm{dl})$, total protein $(\mathrm{g} / \mathrm{dl})$ and albumen $(\mathrm{g} / \mathrm{dl})$ concentration were determined in plasma samples by commercial kits.

Data were subjected to a factorial arrangement $(2 \times 4)$, statistical analysis using General Linear Model of SAS (SAS Institute, 2004). Means were separated by Duncan Multiple Range Test (Duncan, 1955).

\section{RESULTS AND DESCUTION}

\section{1- Productive Traits:}

Impact of supplemental Zinc (Zn) levels, sources and their interaction on feed intake, feed conversion, egg number, weight and mass of Golden Montazah laying hens are presented in tables 3 and 4 . Concerning the effect of different levels of zinc, it was clear to note that there was a significant decrease in feed intake with the two levels 50 and $150 \mathrm{mg}$ supplemental zinc/Kg diet during the first period (24-28 Wks of age) while during the third period (32-36 Wks of age) the lowest feed intake was observed with the two levels of 50 and $100 \mathrm{mg}$ zinc/Kg diet. This decrement in feed intake may be due to increasing of $\mathrm{Zn}$ levels which can reduce the feed intake (Kincaid et al. 1997). When broiler fed diet supplemented with different level of zinc 40, 80 and $120 \mathrm{zinc} / \mathrm{Kg}$ diet, feed intake were significantly decreased by increasing the level of zinc (Amira, 2009). On the other hand, Bartlett and Smith (2003) and Shyam et al. (2008) observed that broiler fed diets supplemented with zinc did not show any significant effect on feed intake. 
Table (3): Productive performance of Golden Montazah laying hens as affected by levels and sources of zinc supplementation during the experimental period (24- 36 wks of age).

\begin{tabular}{|c|c|c|c|c|c|c|c|c|c|c|}
\hline \multirow{2}{*}{ Items } & \multicolumn{5}{|c|}{ Levels of zinc $\mathrm{mg} / \mathrm{kg}$ diet } & \multicolumn{5}{|c|}{ Source of zinc } \\
\hline & Control & 50 & 100 & 150 & +SEM & Sig. & Inorganic & Organic & 土SEM & Sig. \\
\hline \multicolumn{11}{|c|}{ Feed intake (kg/hen/period) } \\
\hline First period (24-28) & $2.05^{\mathrm{a}}$ & $1.89^{\mathrm{b}}$ & $2.03^{\mathrm{a}}$ & $1.88^{b}$ & \pm 0.124 & $*$ & 1.97 & 1.95 & \pm 0.133 & NS \\
\hline Second period (28-32) & $2.36^{\mathrm{a}}$ & $2.42^{\mathrm{a}}$ & $2.36^{\mathrm{a}}$ & $2.13^{b}$ & \pm 0.189 & $*$ & $2.22^{\mathrm{b}}$ & $2.42^{\mathrm{a}}$ & \pm 0.211 & $*$ \\
\hline Third period $\quad(32-36)$ & $2.81^{\mathrm{a}}$ & $2.63^{\mathrm{b}}$ & $2.63^{b}$ & $2.76^{\mathrm{a}}$ & \pm 0.122 & $*$ & $2.64^{b}$ & $2.77^{\mathrm{a}}$ & \pm 0.201 & $*$ \\
\hline Overall mean & $2.41^{\mathrm{a}}$ & $2.31^{\mathrm{ab}}$ & $2.34^{\mathrm{a}}$ & $2.25^{\mathrm{b}}$ & \pm 0.201 & $*$ & 2.27 & 2.38 & \pm 0.201 & NS \\
\hline \multicolumn{11}{|c|}{ Feed conversion (kg feed/kg egg mass) } \\
\hline First period (24-28) & $3.08^{\mathrm{a}}$ & $2.52^{\mathrm{b}}$ & $2.62^{\mathrm{ab}}$ & $2.95^{\mathrm{ab}}$ & \pm 0.031 & * & $2.90^{\mathrm{a}}$ & $2.69^{\mathrm{b}}$ & \pm 0.142 & $*$ \\
\hline Second period (28-32) & $3.23^{\mathrm{a}}$ & $2.91^{b}$ & $2.69^{c}$ & $3.08^{\mathrm{a}}$ & \pm 0.141 & $*$ & 2.96 & 3.00 & \pm 0.141 & NS \\
\hline Third period (32-36) & $3.61^{\mathrm{a}}$ & $2.82^{c}$ & $2.82^{\mathrm{c}}$ & $3.55^{\mathrm{a}}$ & \pm 0.182 & $*$ & 3.22 & 3.18 & \pm 0.051 & NS \\
\hline Overall mean & $3.31^{\mathrm{a}}$ & $2.75^{\mathrm{b}}$ & $2.71^{\mathrm{b}}$ & $3.19^{\mathrm{ab}}$ & \pm 0.124 & $*$ & 3.03 & 2.95 & \pm 0.121 & NS \\
\hline \multicolumn{11}{|l|}{ Egg Number (hen/period) } \\
\hline First period $(24-28)$ & $14.15^{\mathrm{b}}$ & $15.79^{\mathrm{a}}$ & $15.54^{\mathrm{a}}$ & $13.48^{\mathrm{c}}$ & \pm 0.537 & $*$ & $14.26^{\mathrm{b}}$ & $15.22^{\mathrm{a}}$ & \pm 0.078 & $*$ \\
\hline Second period (28-23) & $15.18^{\mathrm{b}}$ & $17.03^{\mathrm{a}}$ & $17.44^{\mathrm{a}}$ & $14.40^{\mathrm{c}}$ & \pm 0.811 & $*$ & $15.51^{\mathrm{b}}$ & $16.52^{\mathrm{a}}$ & \pm 0.099 & $*$ \\
\hline Third period $(32-36)$ & $16.02^{\mathrm{b}}$ & $18.37^{\mathrm{a}}$ & $18.47^{\mathrm{a}}$ & $15.79^{b}$ & \pm 0.622 & $*$ & $16.53^{\mathrm{b}}$ & $17.79^{\mathrm{a}}$ & \pm 0.311 & $*$ \\
\hline Overall mean & $15.12^{\mathrm{b}}$ & $17.06^{\mathrm{a}}$ & $17.15^{\mathrm{a}}$ & $14.56^{\mathrm{c}}$ & \pm 0.611 & $*$ & $15.43^{\mathrm{b}}$ & $16.51^{\mathrm{a}}$ & \pm 0.621 & $*$ \\
\hline \multicolumn{11}{|l|}{ Egg Weight (g) } \\
\hline First period (24-28) & $47.22^{\mathrm{b}}$ & $47.38^{\mathrm{ab}}$ & $49.79^{\mathrm{ab}}$ & $47.13^{b}$ & \pm 0.833 & $*$ & 47.76 & 48.00 & \pm 0.112 & NS \\
\hline Second period (28-32) & 48.01 & 48.75 & 50.18 & 48.02 & \pm 0.871 & NS & 48.42 & 49.06 & \pm 0.205 & NS \\
\hline Third period $(32-36)$ & $48.72^{\mathrm{b}}$ & $50.82^{\mathrm{a}}$ & $50.57^{a}$ & $49.15^{\mathrm{b}}$ & \pm 0.791 & $*$ & 50.07 & 49.55 & \pm 0.291 & NS \\
\hline Over all mean & 47.98 & 48.98 & 50.18 & 48.10 & \pm 0.725 & NS & 48.75 & 48.87 & \pm 0.116 & NS \\
\hline \multicolumn{11}{|l|}{ Egg mass (kg/hen) } \\
\hline First period (24-28) & $0.668^{b}$ & $0.748^{\mathrm{a}}$ & $0.774^{\mathrm{a}}$ & $0.635^{\mathrm{c}}$ & \pm 0.050 & $* *$ & $0.681^{b}$ & $0.731^{\mathrm{a}}$ & \pm 0.012 & $*$ \\
\hline Second period (28-32) & $0.730^{\mathrm{c}}$ & $0.830^{\mathrm{b}}$ & $0.875^{\mathrm{a}}$ & $0.691^{\mathrm{d}}$ & \pm 0.036 & $* *$ & $0.752^{\mathrm{b}}$ & $0.811^{\mathrm{a}}$ & \pm 0.019 & $*$ \\
\hline Third period $(32-36)$ & $0.781^{b}$ & $0.932^{\mathrm{a}}$ & $0.934^{\mathrm{a}}$ & $0.776^{\mathrm{b}}$ & \pm 0.064 & $* *$ & $0.829^{b}$ & $0.883^{\mathrm{a}}$ & \pm 0.120 & $*$ \\
\hline Overall mean & $0.726^{\mathrm{b}}$ & $0.837^{\mathrm{a}}$ & $0.861^{\mathrm{a}}$ & $0.701^{\mathrm{b}}$ & \pm 0.066 & $* *$ & $0.754^{\mathrm{b}}$ & $0.809^{\mathrm{a}}$ & \pm 0.051 & $*$ \\
\hline
\end{tabular}

${ }^{\text {abcd }}$ Means in the same row with different letters differ significantly.

NS; Non significant, $*: \mathrm{p} \leq 0.05 \quad * *: \mathrm{p} \leq 0.01$

SEM; Stander Error Mean. 
Concerning the feed conversion, the best feed conversion value was recorded for hens fed diets supplemented with $50 \mathrm{mg}$ zinc/kg diet during the first and third period (24-28 and 32-36 wk of age). While during the second period (28-32 and wk of age) hens fed diets supplemented with $100 \mathrm{mg}$ zinc/kg recorded the best feed conversion. The improvement in feed conversion was not significant at the level of $150 \mathrm{mg}$ zinc $/ \mathrm{kg}$ through the three periods comparing to the control diet. These results are in agreement with those reported by kucuk et al. (2003) who concluded that adding zinc (30 $\mathrm{mg} / \mathrm{Kg}$ diet) as zinc sulphate $\left(\mathrm{ZnSo}_{4}\right.$ $\mathrm{H}_{2} \mathrm{O}$ ) to the basal diet improved feed efficiency of broiler chicks. Also, Kaya et al. (2000) reported that insignificant improvement in feed conversion were recorded when laying hens were fed different levels of zinc 0, 20, 50, 100 and $200 \mathrm{mg} / \mathrm{Kg}$ diet, the best feed conversion were recorded with those fed $100 \mathrm{mg} / \mathrm{Kg}$ diet. Regarding to egg mass, Results obtained showed that, layers received $100 \mathrm{mg}$ zinc/Kg diet gave the highest values $(\mathrm{P}<0.01)$ of egg mass during the three different periods as compared to the other treatments followed by those fed $50 \mathrm{mg}$ zinc/Kg diet, while the lowest egg mass were recorded with layers fed $150 \mathrm{mg}$ zinc/Kg diet. The overall mean revealed that, feed conversion for layers fed supplemental zinc at the levels 100 and 50 $\mathrm{mg}$ Zinc/Kg diet was improved by 18.13 and $16.9 \%$, respectively, also egg mass was improved by 18.6 and $15.29 \%$, respectively for layers fed the two mentioned zinc levels comparable to the control diet (without zinc supplementation).

As regards to the source of zinc, laying hens fed diets supplemented with organic zinc insignificantly consumed feed intake through the period (24-28 wk of age) while through the second and third periods (28-32 and 32-36 wk of age) the increasing in feed intake were significant. Respecting to feed conversion, there was a significant improvement during the first period when hens fed diets supplemented with the organic zinc while there were no significant differences between the two sources of zinc during the second and third period. Egg mass recoded a significant improvement during the different experimental periods due to the organic zinc source.

As for the overall mean of feed intake and feed conversion as affected by sources of zinc, it was observed that, feeding laying hens diets containing organic zinc increased feed intake and improved feed conversion as compared to those fed inorganic zinc, the results were not significant. The highest value of egg mass was detected for layers fed supplemental organic zinc, the proportional increment was $7.3 \%$ as compared to those fed inorganic zinc. This increasing is due to the high availability of organic zinc compared to inorganic zinc. Organic zinc Sources such as Zn-methionine or Znpropionate were more bioavailability than inorganic zinc sources such as $\mathrm{ZnO}$ or $\mathrm{ZnSo}_{4} \mathrm{H}_{2} \mathrm{O}$ (Spears 1989, wedekind et al. 1992, Hahn and Baker 1993). In addition Amira ,2009) reported that, when chicks fed diet supplemented with different sources of zinc, zinc oxide as inorganic source and BioZinc (zinc methionine) as organic source, significantly highest feed intake was recorded with those fed diet supplemented with organic, also better feed conversion ratio during the growing and finishing periods were recorded. 
Table (4): Productive performance of Golden Montazah laying hens as affected by the interaction between levels and sources of zinc supplementation during the experimental period (24- 36 wks of age).

\begin{tabular}{|c|c|c|c|c|c|c|c|c|c|c|}
\hline \multirow{2}{*}{ Items } & \multicolumn{4}{|c|}{ Inorganic zinc $\mathrm{mg} / \mathrm{kg}$ diet } & \multicolumn{6}{|c|}{ Organic zinc mg/kg diet } \\
\hline & Control & 50 & 100 & 150 & Control & 50 & 100 & 150 & +SEM & Sig \\
\hline \multicolumn{11}{|c|}{ Feed intake (kg/hen/period) } \\
\hline First period $\quad(24-28)$ & $2.11^{\mathrm{a}}$ & $1.90^{\mathrm{b}}$ & $1.97^{\mathrm{b}}$ & $1.88^{\mathrm{bc}}$ & $1.99^{\mathrm{b}}$ & $1.87^{\mathrm{c}}$ & $2.08^{\mathrm{a}}$ & $1.87^{\mathrm{c}}$ & \pm 0.131 & $*$ \\
\hline Second period (28-32) & $2.12^{\mathrm{c}}$ & $2.33^{\mathrm{b}}$ & $2.33^{\mathrm{b}}$ & $2.08^{c}$ & $2.60^{\mathrm{a}}$ & $2.50^{\mathrm{a}}$ & $2.38^{b}$ & $2.18^{c}$ & \pm 0.145 & $*$ \\
\hline Third period $\quad(32-36)$ & $2.83^{\mathrm{a}}$ & $2.49^{\mathrm{b}}$ & $2.51^{\mathrm{b}}$ & $2.74^{\mathrm{b}}$ & $2.79^{\mathrm{a}}$ & $2.77^{\mathrm{a}}$ & $2.75^{\mathrm{a}}$ & $2.77^{\mathrm{a}}$ & \pm 0.201 & $*$ \\
\hline Over all mean & $2.35^{\mathrm{b}}$ & $2.24^{\mathrm{c}}$ & $2.27^{\mathrm{bc}}$ & $2.23^{\mathrm{c}}$ & $2.46^{\mathrm{a}}$ & $2.38^{\mathrm{a}}$ & $2.40^{\mathrm{a}}$ & $2.27^{\mathrm{bc}}$ & \pm 0.163 & $*$ \\
\hline \multicolumn{11}{|c|}{ Feed conversion (kg feed/kg egg mass) } \\
\hline First period $\quad(24-28)$ & $3.33^{\mathrm{a}}$ & $2.59^{c}$ & $2.73^{\mathrm{bc}}$ & $2.95^{\mathrm{b}}$ & $2.83^{\mathrm{bc}}$ & $2.45^{\mathrm{c}}$ & $2.51^{\mathrm{c}}$ & $2.95^{\mathrm{b}}$ & \pm 0.142 & $*$ \\
\hline Second period (28-32) & $3.11^{\mathrm{b}}$ & $2.95^{\mathrm{c}}$ & $2.77^{\mathrm{cd}}$ & $2.99^{c}$ & $3.35^{\mathrm{a}}$ & $2.87^{\mathrm{c}}$ & $2.61^{\mathrm{e}}$ & $3.17^{\mathrm{b}}$ & \pm 0.105 & $*$ \\
\hline Third period $\quad(32-36)$ & $3.86^{\mathrm{a}}$ & $2.73^{\mathrm{de}}$ & $2.88^{\mathrm{d}}$ & $3.43^{\mathrm{c}}$ & $3.37^{\mathrm{c}}$ & $2.91^{\mathrm{d}}$ & $2.76^{\mathrm{d}}$ & $3.67^{\mathrm{ab}}$ & \pm 0.063 & $*$ \\
\hline Overall mean & $3.43^{\mathrm{a}}$ & $2.76^{\mathrm{c}}$ & $2.79^{c}$ & $3.12^{\mathrm{b}}$ & $3.17^{\mathrm{b}}$ & $2.74^{\mathrm{c}}$ & $2.63^{\mathrm{cd}}$ & $3.26^{\mathrm{a}}$ & \pm 0.062 & $*$ \\
\hline \multicolumn{11}{|l|}{ Egg Number (hen/period) } \\
\hline First period & $13.65^{\mathrm{c}}$ & $15.33^{b}$ & $14.51^{\mathrm{b}}$ & $13.53^{\mathrm{c}}$ & $14.65^{b}$ & $16.24^{\mathrm{a}}$ & $16.57^{\mathrm{a}}$ & $13.43^{c}$ & \pm 0.632 & $*$ \\
\hline Second period (28-32) & $14.61^{\mathrm{c}}$ & $16.22^{b}$ & $16.87^{\mathrm{a}}$ & $14.33^{\mathrm{c}}$ & $15.75^{b}$ & $17.84^{\mathrm{a}}$ & $18.00^{\mathrm{a}}$ & $14.47^{\mathrm{c}}$ & \pm 0.301 & $*$ \\
\hline Third period $\quad(32-36)$ & $15.48^{c}$ & $17.46^{\mathrm{b}}$ & $17.27^{\mathrm{b}}$ & $15.92^{\mathrm{c}}$ & $16.56^{\mathrm{c}}$ & $19.28^{\mathrm{a}}$ & $19.67^{\mathrm{a}}$ & $15.66^{c}$ & \pm 0.322 & $*$ \\
\hline Overall mean & $14.58^{c}$ & $16.34^{\mathrm{b}}$ & $16.22^{\mathrm{b}}$ & $14.59^{c}$ & $15.65^{\mathrm{bc}}$ & $17.79^{\mathrm{a}}$ & $18.08^{a}$ & $14.52^{\mathrm{c}}$ & \pm 0.415 & $*$ \\
\hline \multicolumn{11}{|l|}{ Egg Weight (g) } \\
\hline First period (24-28) & $46.41^{\mathrm{b}}$ & $47.84^{\mathrm{a}}$ & $49.65^{\mathrm{a}}$ & $47.13^{b}$ & $48.02^{\mathrm{a}}$ & $46.92^{\mathrm{a}}$ & $49.93^{\mathrm{a}}$ & $47.12^{b}$ & \pm 0.931 & $*$ \\
\hline Second period (28-32) & $46.69^{b}$ & $48.70^{\mathrm{a}}$ & $49.78^{a}$ & $48.49^{\mathrm{ab}}$ & $49.33^{\mathrm{a}}$ & $48.79^{\mathrm{a}}$ & $50.58^{a}$ & $47.54^{\mathrm{b}}$ & \pm 0.364 & $*$ \\
\hline Third period $\quad(32-36)$ & $47.42^{\mathrm{b}}$ & $52.21^{\mathrm{a}}$ & $50.48^{a}$ & $50.17^{\mathrm{a}}$ & $50.01^{\mathrm{b}}$ & $49.42^{\mathrm{b}}$ & $50.65^{\mathrm{a}}$ & $48.12^{b}$ & \pm 0.522 & $*$ \\
\hline Overall mean & $46.84^{\mathrm{b}}$ & $49.58^{\mathrm{a}}$ & $49.97^{\mathrm{a}}$ & $48.60^{\mathrm{a}}$ & $49.12^{\mathrm{a}}$ & $48.38^{\mathrm{a}}$ & $50.39^{a}$ & $47.59^{b}$ & \pm 0.561 & $*$ \\
\hline \multicolumn{11}{|l|}{ Egg mass (kg/hen) } \\
\hline First period $\quad(24-28)$ & $0.633^{\mathrm{d}}$ & $0.733^{b}$ & $0.720^{\mathrm{bc}}$ & $0.638^{\mathrm{d}}$ & $0.703^{c}$ & $0.762^{b}$ & $0.827^{\mathrm{a}}$ & $0.633^{\mathrm{d}}$ & \pm 0.031 & $*$ \\
\hline Second period (28-32) & $0.682^{d}$ & $0.790^{c}$ & $0.840^{\mathrm{b}}$ & $0.695^{\mathrm{d}}$ & $0.777^{\mathrm{c}}$ & $0.870^{\mathrm{a}}$ & $0.910^{\mathrm{a}}$ & $0.688^{d}$ & \pm 0.062 & $*$ \\
\hline Third period $\quad(32-36)$ & $0.734^{\mathrm{d}}$ & $0.912^{b}$ & $0.872^{\mathrm{c}}$ & $0.799^{d}$ & $0.828^{c}$ & $0.953^{\mathrm{ab}}$ & $0.996^{\mathrm{a}}$ & $0.754^{\mathrm{d}}$ & \pm 0.022 & $*$ \\
\hline Overall mean & $0.683^{\mathrm{e}}$ & $0.812^{\mathrm{c}}$ & $0.811^{\mathrm{c}}$ & $0.710^{\mathrm{e}}$ & $0.770^{\mathrm{d}}$ & $0.862^{\mathrm{b}}$ & $0.911^{\mathrm{a}}$ & $0.691^{\mathrm{e}}$ & \pm 0.074 & $* *$ \\
\hline
\end{tabular}

abcde means in the same row with different letters differ significantly.

SEM; Stander Error Mean. NS; Non significant, ${ }^{*}: \mathrm{p} \leq 0.05 \quad * *: \mathrm{p} \leq 0.01$ 
Regarding the interaction between zinc levels and sources (table 4), we can conclude that, the overall mean of feed intake was significantly $(\mathrm{P}<0.05)$ differed among treatments, the lowest value of feed intake was recorded with layers fed diet supplemented with $150 \mathrm{mg}$ zinc sulphate $/ \mathrm{kg}$ diet. While the overall mean of feed conversion showed that, layers fed diet supplemented with $100 \mathrm{mg}$ organic zinc/Kg diet gave the best feed conversion followed by those fed $50 \mathrm{mg}$ organic zinc without any significant differences between the two mentioned levels. The proportional improvements were $23.32 \%$ and $20.12 \%$ respectively comparable to the inorganic control. Remarkably adding $\mathrm{Zn}$ to layers diets significantly improved egg mass in all treatments which fed a different level of zinc either inorganic or organic sources compared to control (without adding zinc). The highest overall mean of egg mass was observed for layers fed $100 \mathrm{mg}$ followed by those fed $50 \mathrm{mg}$ supplemental organic zinc, the increment was 33.38 and $26.21 \%$ respectively compared to the control. These improvement achieved by zinc supplementation may be due to the involving of zinc in many biochemical processes supporting life (Chan et al., 1998) and its important roles in metabolism of energy and protein (Ibs and Rink 2003). Also, these improvements may be due to $\mathrm{Zn}$ supplementation which is an essential nutrient required for many physiological functions, including antioxidant function, growth and fertility (Shay and Mangian 2000). The results of this study are in agreement with those reported by Amira, (2009) who found that the best feed conversion was recorded with the chicks fed $80 \mathrm{mg}$ zinc/ $\mathrm{kg}$ diet as $\mathrm{Zn}$ methionine during the period (7-42 day) compared to the control which recorded the worst value, while the highest values of feed intake were recorded with $40 \mathrm{mg}$ organic $\mathrm{Zn}$ and the lowest values were recorded by those fed the control diet without adding $\mathrm{Zn}$.

\section{2- Effect of supplemental zinc in layers diet on zinc concentration of egg (yolk and white):}

Egg zinc concentration as affected by different zinc levels, sources and their interaction is shown in table 5. It was clearly demonstrated that increasing supplemental zinc level from 0.0 to 50,100 and $150 \mathrm{mg} / \mathrm{kg}$ diet significantly $(\mathrm{P}<0.01)$ increased egg zinc content by $10.4,47.2$ and $74.4 \%$ respectively compared to 0.0 zinc unsupplemented diet (control). As regard to the effect of zinc sources, hens fed diets fortified with Zn-methionine accumulated the highest value of zinc in egg components compared to those fed diet contained zinc sulphate $\left(\mathrm{ZnSo}_{4} 7 \mathrm{H}_{2} \mathrm{O}\right)$. The proportional increment was $6.21 \%$.Wedekind et al. (1992) indicated that, the bioavailability of zinc methionine was $206 \%$ compared to that of zinc sulphate. 
Table (5): Egg zinc content (mg/100 g egg) as affected by levels and source of zinc supplementation and their interaction.

\begin{tabular}{|c|c|c|c|c|c|c|c|c|c|c|c|}
\hline \multirow{2}{*}{ Item } & \multicolumn{6}{|c|}{ levels of zinc $\mathrm{mg} / \mathrm{kg}$ diet } & \multicolumn{5}{|c|}{ Source of zinc } \\
\hline & Control & 50 & 100 & 150 & \pm SEM & Sig & Inorganic & Organic & \pm SEM & \multicolumn{2}{|c|}{ Sig } \\
\hline $\begin{array}{l}\text { Egg zinc } \\
\text { content }\end{array}$ & $1.25^{\mathrm{d}}$ & $1.38^{\mathrm{c}}$ & $1.84^{\mathrm{b}}$ & $2.18^{\mathrm{a}}$ & \pm 0.055 & $* *$ & $1.61^{\mathrm{b}}$ & $1.71^{\mathrm{a}}$ & \pm 0.073 & \multicolumn{2}{|c|}{$* *$} \\
\hline \multicolumn{12}{|c|}{ Interaction } \\
\hline \multirow{2}{*}{ Item } & \multicolumn{5}{|c|}{ Inorganic zinc $\mathrm{mg} / \mathrm{kg}$ diet } & \multicolumn{6}{|c|}{ Organic zinc $\mathrm{mg} / \mathrm{kg}$ diet } \\
\hline & Control & 50 & 100 & & 50 & Control & 50 & 100 & 150 & \pm SEM & Sig \\
\hline $\begin{array}{l}\text { Egg zinc } \\
\text { content }\end{array}$ & $1.19^{\mathrm{f}}$ & $1.22^{\mathrm{f}}$ & $1.91^{\mathrm{c}}$ & $2.13^{\mathrm{b}}$ & & $1.31^{\mathrm{e}}$ & $1.54^{\mathrm{d}}$ & $1.77^{\mathrm{d}}$ & $2.23^{\mathrm{a}}$ & \pm 0.088 & $* *$ \\
\hline
\end{tabular}

abcdef means in the same row with different letters differ significantly .

SEM; Stander Error Mean $\quad * *: p \leq 0.01$

Concerning the interaction between Zn levels and sources, a significant increase in egg zinc content was observed in all treatments compared the inorganic control, the best value of $\mathrm{Zn}$ content in egg was observed for hens fed diets supplemented with $150 \mathrm{mg} \mathrm{Zn}$ methionine being 2.23 $\mathrm{mg} / 100 \mathrm{~g}$ egg, followed by those fed diets supplemented with $150 \mathrm{mg}$ inorganic $\mathrm{Zn}$ being $2.13 \mathrm{mg} / 100 \mathrm{~g}$ egg then those fed 100 $\mathrm{mg} \mathrm{Zn}$ methionine being $1.77 \mathrm{mg} / 100 \mathrm{~g}$ egg, the previously increment were 87.39, 78.99 and $48.70 \%$ respectively as compared to the control diet (without supplemental zinc). Obviously the treatment which contain the organic requirements of zinc (organic control) significantly increased the egg zinc content by $10 \%$ compared to the inorganic control, it is may be due to the high bioavailability of zinc methionine compared to zinc sulphate which was source of zinc in the premix ( Wedekind et al 1992). In this respect, Kim and Patterson (2005) and Plaimast et al. (2008) indicated that, zinc deposition in the egg increased linearly as dietary $\mathrm{Zn}$ levels increased. In addition Yang et al. (2004) indicated that egg zinc content increased by 55.67 and $70.21 \%$ when laying hens fed diets containing two different levels of zinc 240 and $840 \mathrm{mg} / \mathrm{kg}$ diet respectively as compared to the control which fed $60 \mathrm{mg}$ zinc. The same authors added that, laying hen might be a good carrier transporting zinc for egg. Mabe et al. (2003) found a significant increase in egg yolk zinc concentration when used the inclusion level of $60 \mathrm{mg} \mathrm{Zn} / \mathrm{kg}$ diet. James et al. (1988) reported that, hens fed on very high levels of zinc (1762 or $1861 \mathrm{mg} / \mathrm{kg}$ diet) from 4 to 40 weeks produced egg contain 57-95 \% zinc more than eggs produced by hens fed control diet which contain $26 \mathrm{mg} \mathrm{Zn} / \mathrm{kg}$ diet. However Skrivan et al. (2005) found no significant differences in egg yolk, white and shell zinc content when he added $80 \mathrm{mg} \mathrm{Zn}$ to laying hen basal diet comparing to the control.

\section{3- Egg Quality:}

Egg shape, yolk and albumen index and shell, yolk and albumen percentage and Haugh unit and shell thickness are presented in tables 6 and 7. The aforementioned egg quality parameters showed no significant effect according to $\mathrm{Zn}$ levels or sources except albumen index and Haugh unit which significantly affected by using different levels of $\mathrm{Zn}$. The preferable results were recorded with 50 $\mathrm{mg} \mathrm{Zn} / \mathrm{kg}$ diet followed by that of $100 \mathrm{mg}$. Also, shell thickness significantly improved as a result of using organic $\mathrm{Zn}$ in diet. 
Table (6): Egg quality of Golden Montazah laying hens as affected by levels and sources of zinc supplementation during the experimental period (24- 36 wks of age).

\begin{tabular}{|c|c|c|c|c|c|c|c|c|c|c|}
\hline \multirow{2}{*}{ Items } & \multicolumn{5}{|c|}{ Levels of zinc $\mathrm{mg} / \mathrm{kg}$ diet } & \multicolumn{5}{|c|}{ Source of zinc } \\
\hline & Control & 50 & 100 & 150 & \pm SEM & Sig & Inorganic & Organic & \pm SEM & Sig \\
\hline Shape index & 75.13 & 74.45 & 74.33 & 75.36 & \pm 0.212 & $\mathrm{NS}$ & 74.70 & 74.93 & \pm 1.643 & $\mathrm{NS}$ \\
\hline Shell percentage & 11.65 & 11.86 & 11.27 & 11.27 & \pm 0.537 & NS & 11.25 & 11.78 & \pm 0.121 & NS \\
\hline Yolk percentage & 33.14 & 33.39 & 34.62 & 34.46 & \pm 0.763 & NS & 33.81 & 34.00 & \pm 0.621 & NS \\
\hline Albumen percentage & 55.21 & 54.74 & 54.11 & 54.27 & \pm 0.740 & NS & 54.94 & 54.22 & \pm 0.801 & NS \\
\hline Yolk index & 24.64 & 25.62 & 24.63 & 22.76 & \pm 0.633 & NS & 24.52 & 24.31 & \pm 0.332 & NS \\
\hline Albumen index & $6.88^{\mathrm{ab}}$ & $8.85^{\mathrm{a}}$ & $7.94^{\mathrm{ab}}$ & $6.52^{b}$ & \pm 0.062 & $*$ & 7.53 & 7.56 & \pm 0.602 & NS \\
\hline Haugh units & $72.90^{\mathrm{ab}}$ & $81.99^{\mathrm{a}}$ & $77.94^{\mathrm{ab}}$ & $71.88^{\mathrm{b}}$ & \pm 0.931 & $*$ & 76.72 & 75.64 & \pm 1.091 & NS \\
\hline Shell thickness & 0.30 & 0.31 & 0.31 & 0.33 & \pm 0.021 & NS & $0.29^{b}$ & $0.33^{\mathrm{a}}$ & \pm 0.054 & 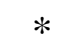 \\
\hline
\end{tabular}

${ }^{\mathrm{ab}}$ means in the same row with different letters differ significantly.

SEM; Stander Error Mean. NS; Non significant, *:p $\leq 0.05$ 
Table (7): Egg quality of Golden Montazah laying hens as affected by the interaction between levels and sources of zinc supplementation during the experimental period (24- 36 wks of age).

\begin{tabular}{|c|c|c|c|c|c|c|c|c|c|c|}
\hline \multirow{2}{*}{ Items } & \multicolumn{4}{|c|}{ Inorganic zinc mg/kg diet } & \multicolumn{6}{|c|}{ Organic zinc mg/kg diet } \\
\hline & Control & 50 & 100 & 150 & Control & 50 & 100 & 150 & \pm SEM & Sig \\
\hline Shape index & 75.69 & 73.77 & 73.68 & 75.68 & 74.57 & 75.13 & 74.98 & 75.03 & \pm 0.1304 & NS \\
\hline Shell percentage & 11.06 & 11.62 & 10.78 & 11.53 & 12.24 & 12.10 & 11.76 & 11.01 & \pm 0.0440 & NS \\
\hline Yolk percentage & 34.10 & 33.27 & 33.44 & 34.43 & 32.19 & 33.52 & 35.80 & 34.49 & \pm 0.0610 & NS \\
\hline Albumen percentage & 54.85 & 55.11 & 55.78 & 54.04 & 55.57 & 54.38 & 52.44 & 54.50 & \pm 0.0605 & NS \\
\hline Yolk index & 24.59 & 25.45 & 24.18 & 23.86 & 24.70 & 25.79 & 25.09 & 21.66 & \pm 0.0330 & NS \\
\hline Albumen index & $6.69^{\mathrm{ab}}$ & $8.51^{\mathrm{ab}}$ & $7.30^{\mathrm{ab}}$ & $7.63^{\mathrm{ab}}$ & $7.07^{\mathrm{ab}}$ & $9.20^{\mathrm{a}}$ & $8.58^{\mathrm{ab}}$ & $5.40^{\mathrm{b}}$ & \pm 0.0125 & $*$ \\
\hline Haugh units & $73.44^{\mathrm{ab}}$ & $81.38^{\mathrm{a}}$ & $74.41^{\mathrm{ab}}$ & $77.64^{\mathrm{ab}}$ & $72.36^{\mathrm{ab}}$ & $82.60^{\mathrm{a}}$ & $81.48^{\mathrm{a}}$ & $66.11^{\mathrm{b}}$ & \pm 0.6130 & $*$ \\
\hline Shell thickness & $0.23^{\mathrm{c}}$ & $0.30^{\mathrm{b}}$ & $0.32^{\mathrm{ab}}$ & $0.31^{\mathrm{ab}}$ & $0.36^{\mathrm{a}}$ & $0.32^{\mathrm{ab}}$ & $0.30^{\mathrm{b}}$ & $0.34^{\mathrm{ab}}$ & \pm 0.0820 & $*$ \\
\hline
\end{tabular}

${ }^{\mathrm{ab}}$ means in the same row with different letters differ significantly.

SEM; Stander Error Mean. NS; Non significant, *:p $\leq 0.05$ 
Concerning the interaction between $\mathrm{Zn}$ levels and sources, it was observed that, albumen index; Haugh unit and shell thicknesses were significantly affected. Supplementation of $50 \mathrm{mg} / \mathrm{kg} \mathrm{Zn}$ as organic zinc gave the preferable value in both of albumen index and Haugh unit. Obviously the treatments which fed supplemental levels of zinc either organic or inorganic source significantly improved shell thickness as compared with the inorganic control .This improvement may be due to the important of zinc function in the formation of egg. In this respect, Zinpro, (2002) indicated that Zinc deficiency affected the quality of the epithelium due to the role of zinc in protein synthesis. Zinc also indirectly affected epithelial secretion by affecting the structure of the epithelium or directly during the synthesis off egg shell membranes. Zinc plays a role in the magnum during the deposition of albumen and in the isthmus where egg shell membranes are produced, further zinc is important also in shell formation in the uterus. In addition, Mabe et al. (2003) showed an improvement in egg shell quality by using $60 \mathrm{mg}$ zinc $/ \mathrm{kg}$ diet in laying hens' basal diet. Also, there were no significant differences for weight of egg components and shell thickness, but values of albumen height and Haugh units were higher in the groups received organic zinc at 25 or $50 \mathrm{mg} / \mathrm{kg}$ than the group fed diet without supplemental zinc (Aliarabi et al. 2007). Egg quality were not significantly differed due to zinc sources except Haugh units values when laying hens fed diets included zinc oxide, zinc sulphate, zinc carbonate and zinc proteinate at level of $140 \mathrm{mg} / \mathrm{kg}$ diet (Idowu et al. 2011).

\section{4- Blood plasma constituents:}

Plasma constituents of Golden Montazah laying hens were measured to show the metabolic status of laying hens and their health as affected by feeding varying levels and sources of zinc and their interaction (Tables 8 and 9). Increasing zinc levels lead to significant differences in plasma $\mathrm{Zn}, \mathrm{Fe}, \mathrm{Ca}$ and $\mathrm{P} \mathrm{mg} / \mathrm{dl}$. So it could concluded that plasma $\mathrm{Zn}$ and $\mathrm{Ca}$ were significantly increased by increasing $\mathrm{Zn}$ levels in diets, however plasma $\mathrm{Fe}$ and $\mathrm{P}$ $\mathrm{mg} / \mathrm{dl}$ were significantly decreased. These results are in agreement with EL- Hossiny and Abo- Elalla (1990) who indicated that, increasing zinc levels in diet impair iron metabolism, they added that the levels of $\mathrm{Ca}$ and $\mathrm{P}$ should be considered in diets when adding zinc.

Moreover, Darlen and Arlette (1979) noticed that serum $\mathrm{Zn}$ content of rats was positively correlated with dietary Zn level.

In the present study, adding zinc as organic source significantly increased plasma zinc, it is may be due to the more availability of zinc methionine compared to zinc sulphate. While there were no significant differences in plasma $\mathrm{Fe}, \mathrm{Ca}$ and $\mathrm{P}$ due to adding diffrent $\mathrm{Zn}$ sources. The interaction between levels and sources of zinc showed a significant difference among treatments in plasma concentration of $\mathrm{Zn}$, $\mathrm{Fe}, \mathrm{Ca}$ and $\mathrm{P}$, the highest plasma zinc was recorded with treatment fed $150 \mathrm{mg}$ zinc methionine. The proportional increment was $56.3 \%$ compared to the control diet. This highest values of zinc in blood produce an effect upon the concentration of zinc in egg, since layer hens diets supplemented with $150 \mathrm{mg}$ zinc as zinc methionine gave the best values for egg zinc content (Table 5). Although, using the highest level of zinc $150 \mathrm{mg}$ as zinc sulphate significantly decreased plasma $\mathrm{Fe}$ by $27.6 \%$ compared to the control diet. Hens received $100 \mathrm{mg}$ zinc methionine diets recorded the highest plasma $\mathrm{Ca}$ however the highest plasma $\mathrm{P}$ was recorded for control group which contain recommended level of inorganic zinc $(50 \mathrm{mg} / \mathrm{kg}$ diet $)$ without supplementation. 
Table (8): Some blood parameters of Golden Montazah laying hens as affected by levels and source of zinc supplementation during the experimental period (24- 36 wks of age).

\begin{tabular}{|c|c|c|c|c|c|c|c|c|c|c|}
\hline \multirow{2}{*}{ Blood parameters } & \multicolumn{6}{|c|}{ Levels of Zinc $\mathrm{mg} / \mathrm{kg}$ diet } & \multicolumn{4}{|c|}{ Source of Zinc } \\
\hline & control & 50 & 100 & 150 & \pm SEM & Sig & Inorganic & Organic & \pm SEM & Sig \\
\hline Zinc mg/dl & $4.1^{\mathrm{cd}}$ & $4.32^{\mathrm{c}}$ & $4.96^{\mathrm{b}}$ & $5.3^{\mathrm{a}}$ & \pm 0.142 & $*$ & $4.26^{\mathrm{b}}$ & $5.08^{\mathrm{a}}$ & \pm 0.131 & $*$ \\
\hline Iron $\mathrm{mg} / \mathrm{dl}$ & $410^{\mathrm{a}}$ & $384.75^{b}$ & $316.4^{\mathrm{c}}$ & $314.8^{\mathrm{c}}$ & \pm 0.035 & $*$ & 350.8 & 343.9 & \pm 0.224 & NS \\
\hline Calcium mg/dl & $10.71^{b}$ & $10.9^{\mathrm{ab}}$ & $11.43^{\mathrm{bc}}$ & $10.89^{\mathrm{a}}$ & \pm 0.392 & $*$ & 10.82 & 11.15 & \pm 0.401 & NS \\
\hline Phosphor mg/dl & $6.77^{\mathrm{a}}$ & $6.02^{b}$ & $5.73^{b c}$ & $5.51^{\mathrm{c}}$ & \pm 0.251 & $*$ & 6.2 & 5.81 & \pm 0.350 & NS \\
\hline Total protein $\mathrm{g} / \mathrm{dl}$ & $7.51^{b}$ & $7.66^{\mathrm{b}}$ & $7.91^{\mathrm{a}}$ & $8.05^{\mathrm{a}}$ & \pm 0.211 & * & $7.18^{\mathrm{b}}$ & $8.51^{\mathrm{a}}$ & \pm 0.506 & * \\
\hline Albumen g/dl & $3.63^{b}$ & $3.66^{\mathrm{b}}$ & $3.74^{\mathrm{a}}$ & $3.9^{\mathrm{a}}$ & \pm 0.025 & $*$ & $3.56^{\mathrm{b}}$ & $3.91^{\mathrm{a}}$ & \pm 0.012 & $*$ \\
\hline Globulin g/dl & $3.88^{\mathrm{c}}$ & $3.99^{\mathrm{bc}}$ & $4.16^{\mathrm{b}}$ & $4.4^{\mathrm{a}}$ & \pm 0.031 & $*$ & $3.62^{b}$ & $4.59^{\mathrm{a}}$ & \pm 0.022 & $*$ \\
\hline $\mathrm{A} / \mathrm{G}$ & $0.93^{\mathrm{a}}$ & $0.92^{\mathrm{a}}$ & $0.91^{\mathrm{a}}$ & $0.89^{b}$ & \pm 0.013 & $*$ & $0.98^{\mathrm{a}}$ & $0.85^{b}$ & \pm 0.073 & $*$ \\
\hline
\end{tabular}

abcd means in the same row with different letters differ significantly.

SEM; Stander Error Mean. NS; Non significant, *:p $\leq 0.05$ 
Table (9): Some blood parameters of Golden Montazah laying hens as affected by the interaction between zinc levels and sources of zinc supplementation during the experimental period (24- $36 \mathrm{wks}$ of age).

\begin{tabular}{|c|c|c|c|c|c|c|c|c|c|c|}
\hline \multirow{2}{*}{ Blood parameters } & \multicolumn{4}{|c|}{ Inorganic zinc mg/kg diet } & \multicolumn{6}{|c|}{ Organic zinc mg/kg diet } \\
\hline & Control & 50 & 100 & 150 & Control & $\mathbf{5 0}$ & 100 & 150 & \pm SEM & Sig \\
\hline Zinc $\mathrm{mg} / \mathrm{dl}$ & $3.59^{\mathrm{d}}$ & $3.55^{\mathrm{d}}$ & $4.91^{\mathrm{b}}$ & $4.99^{\mathrm{b}}$ & $4.61^{\mathrm{c}}$ & $5.08^{\mathrm{b}}$ & $5.01^{\mathrm{b}}$ & $5.61^{\mathrm{a}}$ & \pm 0.093 & $* *$ \\
\hline Iron $\mathrm{mg} / \mathrm{dl}$ & $430^{\mathrm{a}}$ & $351.5^{\mathrm{c}}$ & $311.8^{\mathrm{d}}$ & $311^{\mathrm{d}}$ & $390^{\mathrm{b}}$ & $346^{\mathrm{c}}$ & $321^{\mathrm{d}}$ & $318.6^{\mathrm{d}}$ & \pm 0.072 & $*$ \\
\hline Calcium mg/dl & $10.53^{\mathrm{c}}$ & $10.91^{\mathrm{d}}$ & $10.93^{\mathrm{b}}$ & $10.90^{\mathrm{b}}$ & $10.88^{\mathrm{b}}$ & $10.89^{\mathrm{b}}$ & $11.93^{\mathrm{a}}$ & $10.89^{\mathrm{b}}$ & \pm 0.533 & $*$ \\
\hline PosPor mg/dl & $6.83^{\mathrm{a}}$ & $6.03^{\mathrm{b}}$ & $5.83^{b}$ & $6.11^{\mathrm{b}}$ & $6.70^{\mathrm{a}}$ & $6.01^{\mathrm{b}}$ & $5.63^{\mathrm{bc}}$ & $4.90^{\mathrm{d}}$ & \pm 0.121 & $*$ \\
\hline Total protein $\mathrm{g} / \mathrm{dl}$ & $6.91^{\mathrm{d}}$ & $6.91^{\mathrm{cd}}$ & $7.11^{\mathrm{c}}$ & $7.81^{\mathrm{b}}$ & $8.11^{\mathrm{b}}$ & $8.41^{\mathrm{ab}}$ & $8.71^{\mathrm{a}}$ & $8.79^{a}$ & \pm 0.125 & $* *$ \\
\hline Albumen $\mathrm{g} / \mathrm{dl}$ & $3.45^{\mathrm{d}}$ & $3.44^{\mathrm{d}}$ & $3.54^{\mathrm{c}}$ & $3.81^{\mathrm{b}}$ & $3.81^{\mathrm{b}}$ & $3.89^{\mathrm{a}}$ & $3.95^{\mathrm{a}}$ & $3.99^{\mathrm{a}}$ & \pm 0.022 & $* *$ \\
\hline Globulin g/dl & $3.46^{\mathrm{e}}$ & $3.47^{\mathrm{e}}$ & $3.57^{\mathrm{e}}$ & $4.00^{\mathrm{d}}$ & $4.3^{\mathrm{c}}$ & $4.52^{\mathrm{b}}$ & $4.76^{\mathrm{a}}$ & $4.80^{\mathrm{a}}$ & \pm 0.135 & $* *$ \\
\hline $\mathrm{A} / \mathrm{G}$ & $0.99^{\mathrm{a}}$ & $0.99^{\mathrm{a}}$ & $0.99^{a}$ & $0.95^{\mathrm{a}}$ & $0.89^{b}$ & $0.86^{\mathrm{bc}}$ & $0.83^{\mathrm{c}}$ & $0.83^{c}$ & \pm 0.022 & $*$ \\
\hline
\end{tabular}

abcde means in the same row with different letters differ significantly.

SEM; Stander Error Mean. $\quad$ NS; Non significant, *:p $\leq 0.05, \quad * *: p \leq 0.01$ 
As for total protein, albumin, globulin and $\mathrm{A} / \mathrm{G}$ ratio, analysis of variance showed significant differences due to the different levels, sources of zinc and their interaction. Plasma total protein, albumin and globulin were significantly increased by increasing level of zinc. The highest values of the aforementioned parameters were recorded with $150 \mathrm{mg}$ zinc/ $\mathrm{kg}$ diet. The proportional increment was 7.2, 7.43 and 13.4 respectively comparable to the control without supplemental zinc. Also A/G ratio significantly improved by increasing zinc level, $150 \mathrm{mg}$ zinc improved $\mathrm{A} / \mathrm{G}$ ratio by $4.3 \%$ as compared to the control. These results may be due to the high level of $\mathrm{Zn}$ which plays a role in protein synthesis (Ibs and Rink 2003). Obviously the organic source of zinc significantly increased total protein, albumin and globulin and also improved A/G ratio by $18.5,9.80,26.79$ and $13.3 \%$ respectively compared to the inorganic source. These results are in agreement with the observations of Hassan et al. (2003) who indicated that feeding Mandarah laying hen on diet supplemented with zinc methionine resulted in a significant increase in serum total protein, albumin and globulin as compared to the control group.

Respecting the interaction between supplemental levels and sources of zinc, inspection of obtained data revealed that, increasing supplemental levels of zinc as inorganic source in layer hens diets lead to an advancement of blood total protein, albumin and globulin values than the control, while supplemented layers diets with the same levels as organic source gave the highest significant values $(\mathrm{P}<0.01)$ of the mentioned parameters. As for $A / G$ ratio the best values were recorded with treatments supplemented with 100, $150 \mathrm{mg}$ zinc as organic zinc the proportion of improvement was $16.2 \%$ compared to the control. These results are in agreement with Amira, (2009) who found that the group of chicks fed diets supplemented with organic zinc (Biozink) at either $120 \mathrm{mg}, 80 \mathrm{mg}$ or $40 \mathrm{mg} \mathrm{Zn} / \mathrm{kg}$ diet recorded the highest total protein, globulin and significantly differed compared to all other groups which fed the control or 40, 80, $120 \mathrm{mg}$ supplemental Zn as zinc oxide.

\section{CONCLUSION}

Feeding Golden Montazah laying hens diet supplemented with $150 \mathrm{mg}$ zinc as zinc methionine/ $\mathrm{kg}$ diet gave the best concentration of egg zinc being $2.23 \mathrm{mg}$ $/ 100 \mathrm{~g} \mathrm{egg}$ and gave an advancement productive performance. One egg from this enriched zinc egg can supply $19.45 \%$ of the daily zinc requirements for children from 1 to 8 years old. 


\section{REFERENCES}

Aliarabi, H., S.A. Ahmadi, , M.M. HosseiniSiyar, A. Tabatabie, K.H. Saki and N. Ashori (2007). Effect of different level and sources of zinc on egg quality and layer performance. Aust. Poult. Sci. 19: 102-105.

Amira. M. Refaie, (2009). Performance and immunoocompetence of broilers as affected by zinc protein and Pytase supplementation during summer season. Dep. of Animal nutrition. Faculity of Agricultuer. Cairo Univ.

Atukorala, T.M.S. and U.S.de. S. Waidyanatha (1987). Zinc and copper content of some common food. J. Natn. Sci. Coun. Srilanka 15 (1):61-69.

Bales, C. W., R. A. Disilvestro, K. L. Currie, C. S. Plaisted, H. Joung, A. N. Galanos, and P. H. Lin (1994). Marginal zinc deficiency in older adults: Responsiveness of zinc status indicators. J. Am. Coll. Nutr., 13:455 - 462.

Bartlett, J. R. and M. O. Smith (2003). Effects of different levels of zinc on the performance and immunocompetence of broilers under heat stress. Poult. Sci., 82(11): 1580 - 1588.

Chan, S., B. Gerson, and S. Subramanian (1998). The role of copper, molybdenum, selenium and zinc in nutrition and health. Clinlab-med., 18 (4): 673 - 685.

Close, W. H. (1999). Organic minerals for pigs: An update. Proceeding of Our Industry Under the Microscope. Biotechnology Responds. Alltech. European, Middle Eastern and African Lecture Tour.

Darlen, A. H. M. and J. R. Arlette (1979). Interrelationships between zinc and protein levels and source in weanling rats. J. Nutr., 109(2):321 329.

Duncan, D. B. 1955. Multiple range and multiple F Test. Biometrics, 11: 142.

El-Hosseiny, O. M. and S. Abo-Elalla, 1990. Poultry Nutrition fundamentals, text Book, first edition, (Nutrients and feed additives), El-Dar El-Arabia for publishing and distribution.

Food and Agriculture organization of the united nation (2012). Human vitamin and mineral requirement.

Hahn, J. D. and D. H. Baker (1993). Growth and plasma zinc responses of young pigs fed Pharmacological levels of zinc. J. Anim. Sci., 71(11):3020 - 3024.

Hassan, R. A., E. H. El Ganzoury, F. A. Abd El-Ghany and M, A. Shehata (2003). Influence of dietary zinc supplementation with Methionine or microbial Pytase enzyme on productive performance for Mandarah strain. Egypt. Poult. Sci. 23: 776-785.

Ibs, K.H. and L. Rink (2003). Zinc alters immmmune function. J. Nutr., pp: 1452-1456.

Idowu, O.M.O., R.O. Ajuwon, A.O. Oso and O.A. Akinloye (2011). Effect of zinc supplementation on laying performance, serum chemistry and $\mathrm{Zn}$ residual in tibia bone, liver, excreta and egg shell of laying hens. International Journal of poult. Sci. 10 (3) 225-230.

James. L., M. E. Stahl., J. Cook and L. Greger (1988). Zinc, iron and copper contents of eggs from hens fed varying levels of zinc. J. of food composition and analysis. 1(4):309315.

Kaya, S., H. D. Umucalilarm, S. Halilogl and H. Ipek (2000). Effect of dietary vitamin and zinc on egg 
yield and some blood parameters of laying hens. Faculity of veterinary medicine. Secuk University. Konyaturkey.

Khajaren, J., S. Khajaren, C. J. Rapp, T. A. Ward, A. Johnson and T.M. Falker (2006). Effects of zinc and manganese amino acid complexes (Availa- Z/M) on layer production and egg quality.http://us.znpro.com/research IZPA/ZPA0048.htm.

Kim, K. W. and P. H. Patterson (2005). Effects of dietary zinc supplementation on hen performance, ammonia volatilization, and nitrogen retention in manure. J. Environ. Sci. Health B., 40(4):675 - 686.

Kincaid, R. L., B. P. Chew, and J. D. Cronrath, (1997). Zinc oxide and amino acids as sources of dietary zinc for calves: Effect on uptake and immunity. J. Dairy Sci., 80(11): $1381-1388$.

Kucuk, O., N. Sahin, and K. Sahin (2003). Supplemental zinc and vitamin A can alleviate negative effects of heat stress in broiler chickens. Boil. Trace Elem. Res., 94(3):225 - 235.

Mabe, I., C. Rapp, M.M. Bain and Y. Nys (2003). Supplementation of corn soybean meal diet with manganese, copper and zinc from organic or inorganic sources improves egg shell quality in aged laying hens. Poult. Sci., 82: 19031913.

Mahmood, H.M. and I. AL Hazim (2011). Effect of dietary supplementation with different level of sperm egg penetration and fertility traits of broiler breeder chicken. Pakistan. J.of Nutr. 10 (11) 1083-1088.

Paganelli,C.V., A. Olszowka and A.Ar (1974). The avian egg surface area, volume and density. The Center., 79: 319-325.

Plaimast, H., P. Sirchakwal, P. Puwastien and S.Kijparkorn (2008). Effect of supplementary zinc form organic sources on zinc deposition in eggs and laying performance. Journal of veterinary Medicine 38(3) 47-53.

Powell, S. R. (2000). The antioxidant properties of zinc. J. Nutr. 14521456.

Rahman, M.M., M.A. Wahed, G.J. Fchs, A.H. Bayui and J.I. Alvarez (2002). Synergetic effect of zinc and vitamin $\mathrm{A}$ on the biochemical indexes of vitamin A nutrition in children. Am.J. Clin. Nutr., 1: 9298.

Salgueiro, M. J., M. Zubillaga, A. Lysionek, M. I. Sarabia, R. Caro, T. De Paoli, A. Hager, R. Weill and J. Boccio (2000). Zinc as essential micronutrient: A review. Nutr. Res., 20(6):737 -755.

SAS Institute (2004). SAS, Users's Guide. SAS Institute, Inc. Cary, NC.

Sauter, E. A., W. J. Stadelman, V. Harns, and B. A. Mclaren (1951). Methods for measuring yolk index. Poult. Sci., 30:629-630.

Shay, N. F. and H. F. Mangian (2000). Neurobiology of zinc-influenced eating behavior. J.Nutr.,133(55):14935 - 14995.

Shyam Sunder, G., A. K. Panda, N. C. S. Gopinath, S. V. Rama, M. V. L. N. Rao Raju, M. R. Reddy, and Ch. Vijay Kumar (2008). Effects of high levels of zinc supplementation on performance, mineral availability, and immune competence in broiler chickens. J. Appl. Poult. Res., 17(1):79 - 86.

Skrivan, M., V. Skrivanove and M. Marounek (2005). Effect of dietary iron, zinc and copper in layer feed on distribution of these elements in 
eggs, liver, excreta, soil and herbage. Poult. Sci., 84: 1570-1575.

Spears, J.W. (1989). Zinc methionine for ruminants: Relative bioavailability of zinc in lambs and effects of growth and performance of growing heifers, Anim. Sci., 67: 835-843.

Tabatabaie, M. M., H. Aliarabi, A. A. Saki, A. Ahmadi and S. A. Hosseini (2007). Effect of different sources and levels of zinc on egg quality and laying hen performance. Pakistan J of Biological Sci. 10 (19) 3476-3478.

Wedekind, K. L., A. E. Hortin, and D. H. Baker (1992). Methodology for assessing zinc bioavailability: efficacy estimates for zincmethionine, zinc sulfate, and zinc oxide. J. Anim. Sci., 70(1):178 187.
World Health Organization (2002). Quantifying selected major risk to health. World health report, Geneva, Switzerland.

Williams, K. C. (1997). Some factors affecting albumen quality particular reference to Haugh Unit Score. World's Poult. Sci., J.,48:5 -16.

Yang, L.I. E., S. Coa; M. Cheng, L. Chen and K. Chen, 2004. Effect of iron, zinc, iodine and selenium levels in rations on activities of metabolic enzymes of layers and egg quality. Journal of Huazhong Agricultural University, China.

Zinpro (2002). Trace minerals for laying hens. htt:/www.availzmc.com/ technical/layer/page $2 \mathrm{html}$.

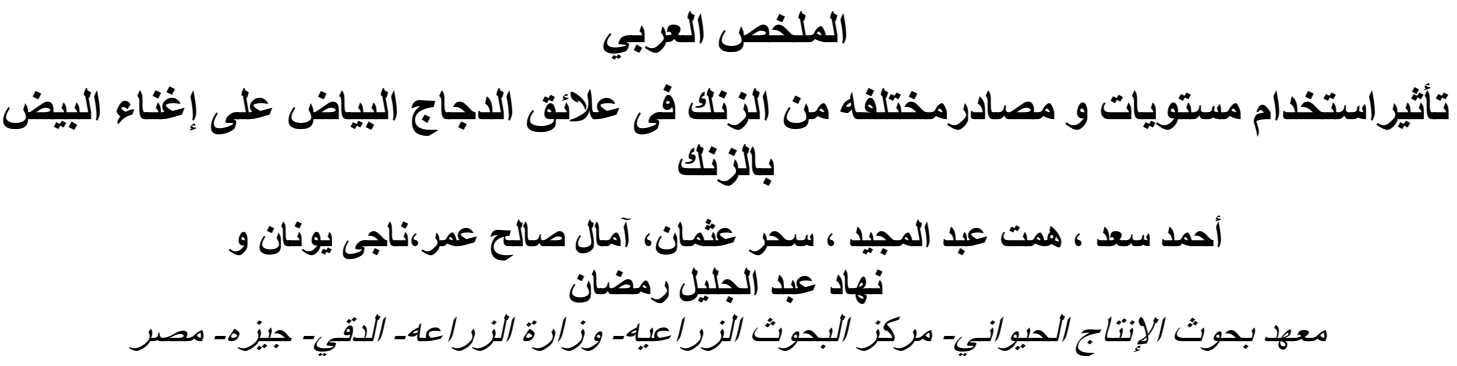

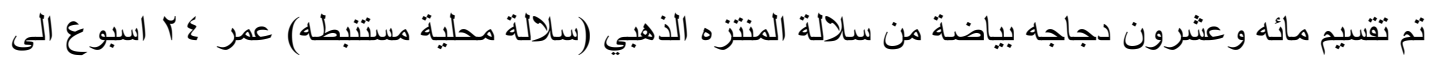

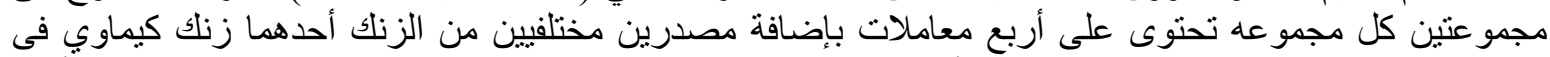

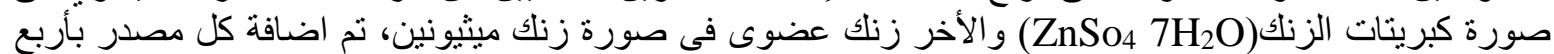

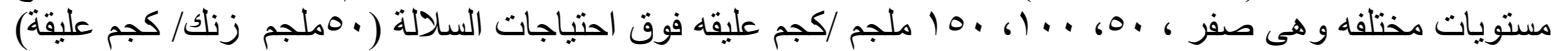

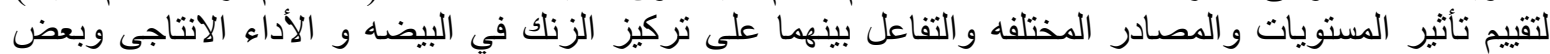

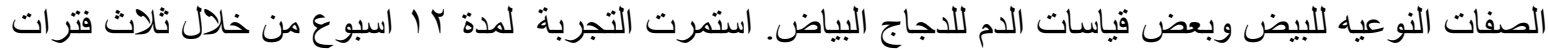

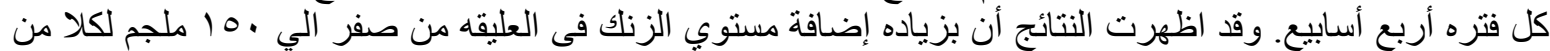

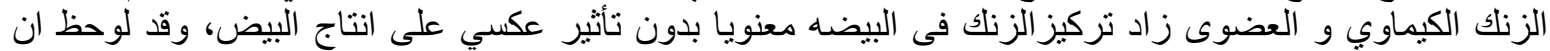

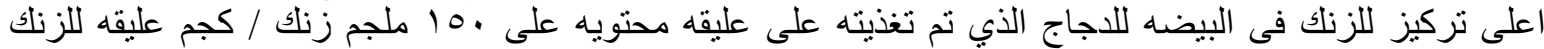

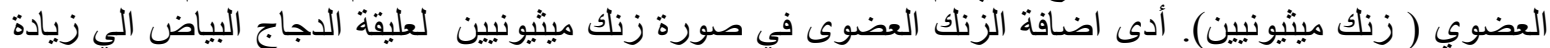

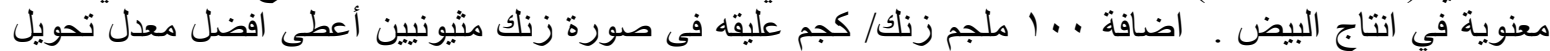

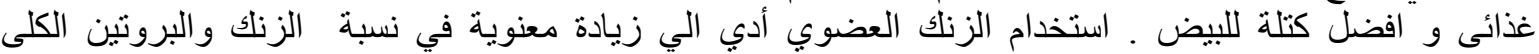

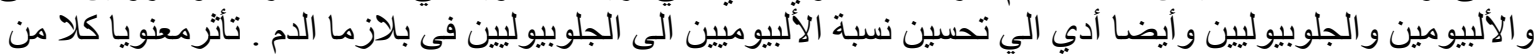

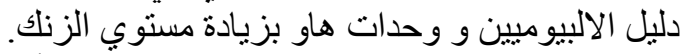

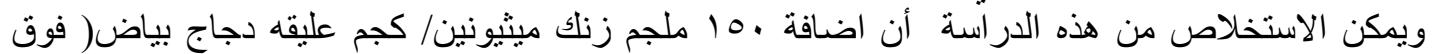

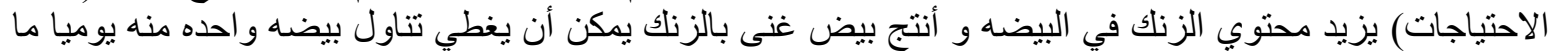

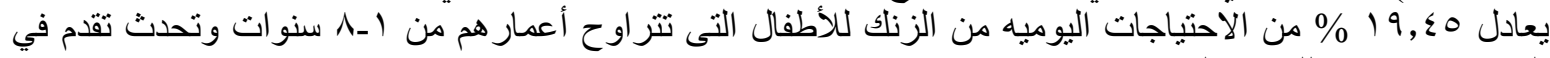

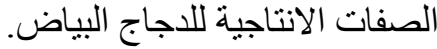

